\title{
PENGARUH METODE PEMBELAJARAN DISCOVERY DAN METODE PEMBELAJARAN INQUIRI TERHADAP KEMAMPUAN PEMECAHAN MASALAH MATEMATIKA TEKNIK
}

\author{
Ukti Lutvaidah \\ Universitas Indraprasta PGRI Jakarta, Arsitektur \\ uktilutvaidah03@gmail.com
}

\begin{abstract}
The purpose of this research is to find out whether there is a difference in mathematical problem solving ability learners use discoverylearning method and inquiri learning method for students of the first semester of the architecture study program of the University of Indraprasta PGRI 2017/2018 school year. The population in this study is the 1st semester student and the sampling is RIA students and the RID students with 56 students are taken on a random basis. This study used experimental research techniques. To obtain data on population and sample researchers using documentation methods and test methods. The research instrument is a matter of essay that amounted to 7 questions. Before the instrument is given to the research respondent, the instrument is tested first by testing the validity and reliability that uses the correlation of the product moment. Test prerequisite data analysis using the Kolmogorov-Smirnov test to test the normality and Levene Test to test the homogeneity. The hypothesis test using the test-T was obtained Thitung is 0.866 and this $=1.674$. The results of the study showed $T$ _hitung $<T$ _tabel then Ho was accepted and rejected Ha who said that there is no difference in the math problem solving skills of learners the method of learning discovery with the method of enquiries learning for students of the first semester of the architecture study program of the University of Indraprasta PGRI 2017/2018 school year.Key Words: Discovery learning method, Inquiri learning method,Problem-Solving Ability Mathematics
\end{abstract}

\begin{abstract}
Abstrak : Tujuan penelitian ini adalah untuk mengetahui ada tidaknya perbedaan kemampuan pemecahan masalah matematika teknik yang diajar menggunakan metode pembelajaran discovery dan metode pembelajaran inquiri pada mahasiswa semester 1 Prodi Arsitektur Universitas Indraprasta PGRI tahun ajaran 2019/2020. Populasi dalam penelitian ini adalah mahasiswa semester 1 dan sampelnya yaitu mahasiswa R1A dan mahasiswa R1D dengan jumlah 56 mahasiswa yang diambil secara random. Penelitian ini menggunakan teknik penelitian eksperimen. Untuk memperoleh data tentang populasi dan sampel peneliti menggunakan metode dokumentasi dan metode tes. Instrumen penelitian berupa soal essay yang berjumlah 7 soal. sebelum instrumen diberikan kepada responden penelitian, maka instrumen diujicobakan terlebih dahulu dengan menguji validitas dan reliabilitas yang menggunakan korelasi product moment. Uji prasyarat analisis data menggunakan uji Kolmogorov-Smirnov untuk menguji normalitas dan Levene Test untuk menguji homogenitas. Uji Hipotesis menggunaka uji-t diperoleh $t_{\text {hitung }}$ adalah 0,866 dan $t_{\text {tabel }}=1,674$. Hasil penelitian menunjukan $t_{\text {hitung }}<t_{\text {tabel }}$ maka Ho diterima dan menolak Ha yang menayatakan bahwa tidak ada perbedaan kemampuan pemecahan masalah matematika peserta didik yang metode pembelajaran discovery dengan metode pembelajaran inquiri pada mahasiswa semester 1
\end{abstract} Universitas Indraprasta tahun ajaran 2019/2020.

Kata Kunci : Metode pembelajaran Discovery, Metode Pembelajaran Inquiri, dan Kemampuan Pemecahan Masalah MatematikaTeknik

\section{PENDAHULUAN}

Pendidikan yang baik merupakan salah satu upaya dalam meningkatkan mutu Sumber Daya Manusia (SDM). Diantaranya yang bertanggung jawab dalam pelaksanaan pendidikan adalah Dinas Pendidikan dan Kebudayaan. Pendidikan merupakan ujung tombak dalam pengembangan sumber daya manusia harus mampu berperan aktif dalam meningkatkan kualitas maupun kuantitas. Upaya pengembangan pendidikan tersebut harus sesuai dengan proses pengajaran yang tepat agar anak didik dapat menerima pelajaran dengan baik.

Proses pembelajaran akan lebih baik jika terjadi kerjasama diantara peserta didik. peserta didik yang memiliki tingkat pola pikir rendah akan dibantu oleh peserta didik yang memiliki tingkat pola pikir tinggi sehingga proses pembelajaran akan lebih bermakna dan hasilnya akan lebih memuaskan. Oleh karena itu, proses pembelajaran 
dengan paradigma lama harus dirubah dengan paradigma baru. Paradigma lama, pengajar lebih aktif (teachers - centered) sedangkan peserta didik lebih menjadi objek sedangkan paradigma baru peserta didik harus aktif dalam proses belajar dan pengajar membimbing dan memotivasi.

Pada pelaksanaan pembelajaran matematika teknik, pengajar hendaknya tidak ditekankan pada tujuan yang bersifat teoritis saja tetapi juga ditekankan pada proses belajar dan hasil belajar. Pemilihan pembelajaran sangat menentukan kualitas pengajaran yang merupakan proses dan hasil belajar mengajar. Kualitas pembelajaran selalu terkait dengan penggunaan model pengajaran yang optimal, ini berarti untuk mencapai kualitas pengajaran yang tinggi harus diorganisasikan dengan strategi yang tepat pula. Selain itu untuk mengembangkan kemampuan menggunakan matematika dalam discovery dan mengomunikasikan ide atau gagasan dengan menggunakan simbol, tabel, diagram, dan media lain. Metode pembelajaran discovery merupakan fokus dalam pembelajaran matematika yang mencakup masalah tertutup dengan solusi tunggal, masalah terbuka dengan solusi tidak tunggal, dan masalah dengan berbagai cara penyelesaian. Untuk meningkatkan kemampuan memecahkan masalah perlu dikembangkan keterampilan memahami masalah, membuat model matematika, menyelesaikan masalah, dan menafsirkan solusinya. Sedangkan metode pembelajaran inquiri merupakan suatu proses untuk memperoleh dan mendapatkan informasi dengan melakukan observasi dan atau eksperimen, dengan menghadirkan dunia nyata ke dalam kelas dan mendorong siswa untuk membuat hubungan antara pengetahuan yang dimilikinya dengan penerapan dalam kehidupan.

Zulkardi (2007 : 18) dalam artikelnya memaparkan bahwa masalah utama dalam pendidikan di Indonesia adalah rendahnya hasil belajar siswa disekolah. Dalam konteks pendidikan matematika contohnya, hasil belajar yang dimaksud tidak hanya pada kemampuan mengerti matematika sebagai pengetahuan (cognitive) tetapi juga aspek sikap (attitud). Agar proses belajar mengajar matematika memungkinkan terjadinya transfer belajar.
Hudoyo (1997: 122) menyarankan agar guru mengutamakan pengertian terhadap konsep dan teorema ini berarti guru harus sering menggunakan model penemuan. Dengan terlibatnya siswa sering aktif dalam menemukan dan memahami konsep/teorema dapat diharapkan transfer belajar akan tercapai optimal. Setelah pengertian diperoleh siswa memerlukan latihan yang cukup untuk mengorganisasikan atau menstruktur kembali pengamatan-pengamatan yang berhubungan dengan konsep/teorema itu. Latihan-latihan ini dapat diberikan dalam jam pelajaran ini di sekolah atau melalui tugas.

Ketercapain hasil belajar yang diinginkan tidak lepas dari proses belajar-mengajar dikelas, faktor-faktor yang dapat mempengaruhi diantara kemampuan pengajar dalam menyajikan materi pelajaran, metode yang digunakan, suasana belajar-mengajar dikelas, kesiapan peserta didik menerima materi pelajaran dan persiapan pengajar dalam proses belajar-mengajar. Pembelajaran yang berlangsung monoton dan searah akan memberi suasana menjenuhkan, sehingga semua informasi yang telah disampaikan pengajar tidak dapat diterima peseta didik dengan baik. Berbeda dengan suasana belajar yang menarik, penuh ceria dan proses belajar-mengajar dapat berlangsung dua arah dapat memberikan dampak meningkatnya hasil belajar.

Dalam hal ini masalah yang akan diteliti dibatasi tentang perbedaan hasil belajar yang diperoleh peserta didik melalui pendekatan belajar yang menggunakan metode discovery yang menitik beratkan pada proses dan pendekatan pembelajaran yang menggunakan metode inquiri menekankan penemuan dengan menghubungkannya dengan minat belajar peserta didik . Penerapan kedua pendekatan belajar ini sedikit banyak tentu akan berpengaruh terhadap respon peserta didik karena kedua pendekatan ini memiliki karakteristik yang berbeda satu dengan lainnya.

Pendekatan belajar yang berorientasi pada penemuan peserta didik akan memberi ruang gerak yang lebih luas pada peserta didik untuk menyampaikan ide sehingga aktivitas dan kreativitas supaya peserta didik lebih berkembang optimal. Dari perbedaan penggunaan metode 
74 Pengaruh Metode Pembelajaran Discovery dan Metode Pembelajaran Inquiri terhadap Kemampuan Pemecahan Masalah Matematika Teknik

pembelajaran yang ada diharapkan akan mendapatkan masukan tentang penggunaan metode pembelajaran yang lebih efektif untuk digunakan dalam menyampaikan mata kuliah matematika teknik.

\section{Kemampuan Pemecahan Masalah Matematika} Pemecahan masalah merupakan kemampuan dasar yang harus dikuasai oleh siswa. Bahkan tercermin dalam konsep kurikulum berbasis kompetensi. Tuntutan akan kemampuan pemecahan masalah dipertegas secara eksplisit dalam kurikulum tersebut yaitu, sebagai kompetensi dasar yang harus dikembangkan dan diintegrasikan pada sejumlah materi yang sesuai. Pentingnya kemampuan penyelesaian masalah oleh siswa dalam matematika ditegaskan juga oleh Branca (1980):

1. Kemampuan menyelesaikan masalah merupakan tujuan umum pengajaran matematika.

2. Penyelesaian masalah yang meliputi metode, prosedur dan strategi merupakan proses inti dan utama dalam kurikulum matematika .

3. Penyelesaian masalah merupakan kemampuan dasar dalam belajar matematika.

Pandangan bahwa kemampuan menyelesaikan masalah merupakan tujuan umum pengajaran matematika, mengandung pengertian bahwa matematika dapat membantu dalam memecahkan persoalan baik dalam pelajaran lain maupun dalam kehidupan sehari-hari. Oleh karenanya kemampuan pemecahan masalah ini menjadi tujuan umum pembelajaran matematika.

Pemecahan masalah sebagai proses inti dan utama dalam kurikulum matematika, berarti pembelajaran pemecahan masalah lebih mengutamakan proses dan strategi yang dilakukan peserta didik dalam menyelesaikannya dari pada hanya sekedar hasil. Sehingga keterampilan proses dan strategi dalam memecahkan masalah tersebut menjadi kemampuan dasar dalam belajar matematika.

Walaupun kemampuan pemecahan masalah merupakan kemampuan yang tidak mudah dicapai, akan tetapi oleh karena kepentingan dan kegunaannya maka kemampuan pemecahan masalah ini hendaknya diajarkan kepada peserta didik pada semua tingkatan. Berkaitan dengan hal ini, Ruseffendi (1991: 6) mengemukakan beberapa alasan soal-soal tipe pemecahan masalah diberikan kepada siswa:

1. Dapat menimbulkan keingintahuan dan adanya motivasi, menumbuhkan sifat kreatif.

2. Disamping memiliki pengetahuan dan keterampilan (berhitung dan lain-lain), disyaratkan adanya kemampuan untuk terampil membaca dan membuat pernyataan yang benar;

3. Dapat menimbulkan jawaban yang asli, baru, khas, dan beraneka ragam, serta dapat menambah pengetahuan baru;

4. Dapat meningkatkan aplikasi dari ilmu pengetahuan yang sudah diperolehnya;

5. Mengajak siswa memiliki prosedur pemecahan masalah, mampu membuat analisis dan sintesis, dan dituntut untuk membuat evaluasi tehadap hasil pemecahannya;

6. Merupakan kegiatan yang penting bagi siswa yang melibatkan bukan saja satu bidang studi tetapi mungkin bidang atau pelajaran lain.

Cara memecahkan masalah dikemukakan oleh beberapa ahli, diantaranya Dewey dan Polya. Dewey dalam bukunya W. Gulo (2001:115) memberikan enam langkah utama dalam memecahkan masalah:

1. Merumuskan masalah

2. Menelaah masalah

3. Merumuskan hipotesis

4. Mengumpulkan dan mengelompokkan data sebagai bahan pembuktian hipotesis

5. Pembuktian hipotesis

6. Menentukan pilihan penyelesaian

Sedangkan menurut Polya (1973: 5) yang dikutip Zakaria menguraikan proses yang dapat dilakukan pada setiap langkah pemecahan masalah. Proses tersebut terangkum dalam empat langkah berikut:

1. Memahami Masalah (Understanding the problem)

2. Merencanakan penyelesaian (Devising a plan)

3. Melaksanakan rencana (Carrying out the plan)

4. Memeriksa proses dan hasil (Looking back) 


\section{Metode Pembelajaran Matematika}

Uzer Usman (2008:21) berpendapat bahwa dalam menciptakan kondisi belajar mengajar yang efektif, setidaknya ada lima variabel yang menentukan keberhasilan siswa, yaitu melibatkan siswa secara aktif, menarik minat dan perhatian siswa, membangkitkan motivasi siswa dan menggunakan alat peraga yang tepat. Melihat dari fenomena tersebut, maka perlu dicari strategi pembelajaran yang tepat agar dalam proses pembelajaran peserta didik menjadi tertarik dan berminat terhadap mata kuliah matematika teknik. Proses pembelajaran yang menarik dan minat peserta didik yang tinggi dalam kegiatan belajar mengajar diharapkan akan meningkatkan hasil belajar peserta didik. Dalam penelitian ini difokuskan pada penggunaan metode pembelajaran yang tepat, sehingga diharapkan hasil belajar peseta didik meningkat.

Metode pembelajaran dapat diartikan sebagai cara yang digunakan untuk mengimplementasikan rencana yang sudah disusun dalam bentuk kegiatan nyata dan praktis untuk mencapai tujuan pembelajaran. Terdapat beberapa metode pembelajaran yang dapat digunakan untuk mengimplementasikan strategi pembelajaran, diantaranya: (1) ceramah; (2) demonstrasi; (3) diskusi; (4) simulasi; (5) laboratorium; (6) pengalaman lapangan; (7) brainstorming; (8) debat, (9) simposium, dan sebagainya.

Metode pembelajaran discovery (penemuan) adalah metode mengajar yang mengatur pengajaran sedemikian rupa sehingga anak memperoleh pengetahuan yang sebelumnya belum diketahuinya itu tidak melalui pemberitahuan, sebagian atau seluruhnya ditemukan sendiri. Dalam pembelajaran discovery (penemuan) kegiatan atau pembelajaran yang dirancang sedemikian rupa sehingga peserta didik dapat menemukan konsep-konsep dan prinsipprinsip melalui proses mentalnya sendiri. Dalam menemukan konsep, peserta didik melakukan pengamatan, menggolongkan, membuat dugaan, menjelaskan, menarik kesimpulan dan sebagainya untuk menemukan beberapa konsep atau prinsip. Pengajar hanya bertindak sebagai pembimbing dan fasilitator yang mengarahkan peserta didik untuk menemukan konsep, dalil, prosedur, algoritma dan semacamnya.

Langkah-langkah pembelajaran Discovery dalah sebagai berikut:

1) Identifikasi kebutuhan siswa;

2) Seleksi pendahuluan terhadap prinsipprinsip, pengertian konsep dan generalisasi pengetahuan;

3) Seleksi bahan, problema/ tugas-tugas;

4) Membantu dan memperjelas tugas/ problema yang dihadapi siswa serta peranan masingmasing siswa;

5) Mempersiapkan kelas dan alat-alat yang diperlukan;

6) Mengecek pemahaman siswa terhadap masalah yang akan dipecahkan;

7) Memberi kesempatan pada siswa untuk melakukan penemuan;

8) Membantu siswa dengan informasi/ data jika diperlukan oleh siswa;

9) Memimpin analisis sendiri (self analysis) dengan pertanyaan yang mengarahkan dan mengidentifikasi masalah;

10) Merangsang terjadinya interaksi antara siswa dengan siswa;

11) Membantu siswa merumuskan prinsip dan generalisasi hasil penemuanny.

Sumantri (1999:164) menyatakan bahwa model pembelajaran inkuiri adalah cara penyajian pelajaran yang memberi kesempatan kepada siswa untuk menemukan dengan atau tanpa bantuan guru. Model pembelajaran inkuiri adalah proses belajar yang memberikan kesempatan pada siswa untuk menguji dan menafsirkan problem secara sistematika yang memberikan konklusi berdasarkan pembuktian (Nasution, 1992:128)

Sanjaya (2008:202) menyatakan bahwa pembelajaran inkuiri mengikuti langkah-langkah sebagai berikut:

1) Orientasi

Pada tahap ini guru melakukan langkah untuk membina suasana atau iklim pembelajaran yang kondusif. Hal yang dilakukan dalam tahap orientasi ini adalah:

a) Menjelaskan topik, tujuan, dan hasil belajar yang diharapkan dapat dicapai oleh siswa. 
b) Menjelaskan pokok-pokok kegiatan yang harus dilakukan oleh siswa untuk mencapai tujuan. Pada tahap ini dijelaskan langkahlangkah inkuiri serta tujuan setiap langkah, mulai dari langkah merumuskan merumuskan masalah sampai dengan merumuskan kesimpulan.

c) Menjelaskan pentingnya topik dan kegiatan belajar. Hal ini dilakukan dalam rangka memberikan motivasi belajar siswa.

2) Merumuskan masalah

Merumuskan masalah merupakan langkah membawa siswa pada suatu persoalan yang mengandung teka-teki. Persoalan yang disajikan adalah persoalan yang menantang siswa untuk memecahkan teka-teki itu. Tekateki dalam rumusan masalah tentu ada jawabannya, dan siswa didorong untuk mencari jawaban yang tepat. Proses mencari jawaban itulah yang sangat penting dalam pembelajaran inkuiri, oleh karena itu melalui proses tersebut siswa akan memperoleh pengalaman yang sangat berharga sebagai upaya mengembangkan mental melalui proses berpikir.

\section{3) Merumuskan hipotesis}

Hipotesis adalah jawaban sementara dari suatu permasalahan yang dikaji. Sebagai jawaban sementara, hipotesis perlu diuji kebenarannya. Salah satu cara yang dapat dilakukan guru untuk mengembangkan kemampuan menebak (berhipotesis) pada setiap anak adalah dengan mengajukan berbagai pertanyaan yang dapat mendorong siswa untuk dapat merumuskan jawaban sementara atau dapat merumuskan berbagai perkiraan kemungkinan jawaban dari suatu permasalahan yang dikaji.

4) Mengumpulkan data

Mengumpulkan data adalah aktifitas menjaring informasi yang dibutuhkan untuk menguji hipotesis yang diajukan. Dalam pembelajaran inkuiri, mengumpulkan data merupakan proses mental yang sangat penting dalam pengembangan intelektual. Proses pemgumpulan data bukan hanya memerlukan motivasi yang kuat dalam belajar, akan tetapi juga membutuhkan ketekunan dan kemampuan menggunakan potensi berpikirnya.

5) Menguji hipotesis

Menguji hipotesis adalah menentukan jawaban yang dianggap diterima sesuai dengan data atau informasi yang diperoleh berdasarkan pengumpulan data. Menguji hipotesis juga berarti mengembangkan kemampuan berpikir rasional. Artinya, kebenaran jawaban yang diberikan bukan hanya berdasarkan argumentasi, akan tetapi harus didukung oleh data yang ditemukan dan dapat dipertanggungjawabkan.

6) Merumuskan kesimpulan

Merumuskan kesimpulan adalah proses mendeskripsikan temuan yang diperoleh berdasarkan hasil pengujian hipotesis. Untuk mencapai kesimpulan yang akurat sebaiknya guru mampu menunjukkan pada siswa data mana yang relevan.Alasan rasional penggunaan pembelajaran dengan pendekatan inkuiri adalah bahwa siswa akan mendapatkan pemahaman yang lebih baik mengenai matematika dan akan lebih tertarik terhadap matematika jika mereka dilibatkan secara aktif dalam "melakukan" penyelidikan. Investigasi yang dilakukan oleh siswa merupakan tulang punggung pembelajaran dengan pendekatan inkuiri. Investigasi ini difokuskan untuk memahami konsep-konsep matematika dan meningkatkan keterampilan proses berpikir ilmiah siswa. Sehingga diyakini bahwa pemahaman konsep merupakan hasil dari proses berpikir ilmiah tersebut.

\section{METODOLOGI}

Penelitian ini metoda yang digunakan adalah metoda eksperimen. Arikunto (2002:272) menyatakan bahwa penelitian eksperimen adalah penelitian yang dilakukan untuk mengetahui hubungan sebab akibat antara satu perlakuan dengan perlakuan lain. Faktor pertama adalah 
metode pembelajaran dan Faktor kedua adalah kemampuan pemecahan masalah matematika teknik pada mahasiswa semester 1 Prodi Arsitektur Universitas Indraprasta PGRI.

Populasi dalam penelitian ini adalah para mahasiswa semester 1 Prodi Arsitektur Universitas Indraprasta PGRI yang terdiri dari 8 kelas yaitu kelas R1A, R1B, R1C, R1D, S1A, S1B, S1C, dan S1D. Berdasarkan pendapat Suharsimi Arikunto (1996 : 120) sebagai ancer-ancer bila subjeknya kurang dari 100, lebih baik diambil semua, tetapi jika subjeknya besar dapat diambil antara $10-15 \%$ atau $20-25 \%$ atau lebih, maka ampel penelitian adalah mahasiswa kelas R1A dan mahasiswa kelas R1D dengan jumlah mahasiswa sebanyak 56. Teknik pengumpulan data menggunakan metode dokumentasi untuk mengetahui para mahasiswa yang menjadi populasi dan sampel serta untuk mengetahui nilai ulangan. Dan Metode Tes untuk mengetahui data nilai mahasiswa.

Instrumen penelitian ini berupa soal essay, jumlah 7 soal yang dikerjakan dalam waktu $2 \times 45$ menit dengan materi bab Program Linear. Sebelum instrumen digunakan untuk penelitian maka terlebih dahulu diujicobakan di kelas uji coba. Hal ini bertujuan agar dalam penelitian responden tidak merasa kesulitan dalam menangkap maksud peneliti. Setelah diujicoba, maka hasil tes dianalisis mencakup validitas, reabilitas, tingkat kesukaran dan daya beda. Uji prasyarat analisis data menggunakan uji Kolmogorov-Smirnov untuk menguji normalitas dan uji $F$ untuk menguji homogenitas. Uji Hipotesis menggunakan uji-t untuk mengetahui ada tidaknya perbedaan kemampuan pemecahan masalah matematika teknik yang diajar menggunakan metode pembelajaran discovery dan metode pembelajaran inquiri pada mahasiswa semester 1 Prodi Arsitektur Universitas Indraprasta PGRI tahun ajaran 2019/2020.

\section{HASIL DAN PEMBAHASAN}

korelasi product moment untuk mengetahui validitas setiap soal dan koefisien alpha untuk mengetahui reliabilitas instrument. Dari 10 aitem hanya 7 aitem yang dinyatakan valid dan reliabel. Setelah instrumen diujicobakan, instrumen tersebut di uji prasyarat dan di uji hipotesis. Uji prasyarat analisis data menggunakan uji Kolmogorov-Smirnov untuk menguji normalitas dan Levene Test untuk menguji homogenitas dengan bantuan SPSS 20.00, adapun hasil perhitungannya yaitu:

Tabel 1. Rekapitulasi Hasil Pengujian Normalitas

\begin{tabular}{|c|c|c|c|}
\hline \multirow[t]{2}{*}{ 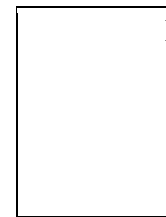 } & \multirow[t]{2}{*}{$\mathrm{N}$} & $\begin{array}{l}\text { Metode } \\
\text { Pembelajara } \\
\text { n }\end{array}$ & $\begin{array}{l}\text { Kemampuan } \\
\text { Pemecahan } \\
\text { Masalah } \\
\text { Matematika }\end{array}$ \\
\hline & & 56 & 56 \\
\hline \multirow{2}{*}{$\begin{array}{l}\text { Normal } \\
\text { Paramete } \\
\mathrm{rs}^{\mathrm{a}}\end{array}$} & Mean & 72.71 & 84.04 \\
\hline & \begin{tabular}{|l} 
Std. \\
Deviation
\end{tabular} & 4.816 & 5.927 \\
\hline \multirow{3}{*}{$\begin{array}{l}\text { Most } \\
\text { Extreme } \\
\text { Differenc } \\
\text { es }\end{array}$} & Absolute & .175 & .177 \\
\hline & Positive & .175 & .177 \\
\hline & Negative & .144 & -.136 \\
\hline \multicolumn{2}{|c|}{$\begin{array}{l}\text { Kolmogorov-Smirnov } \\
\text { Z }\end{array}$} & 1.307 & 1.326 \\
\hline \multicolumn{2}{|c|}{ Asymp. Sig. (2-tailed) } & .066 & .059 \\
\hline
\end{tabular}

a. Test distribution is Normal.

Pada tabel 1 terlihat bahwa nilai pada kolom Sig pada metode Kolmogorov-Smirnov untuk semua sampel yaitu Metode pembelajaran $=0,066$ dan kemampuan pemecahan masalah matematika $=0,059$ dimana keduanya lebih besar dari 0,05, sehingga $\mathrm{H}_{0}$ diterima, dengan kata lain bahwa data dari semua sampel pada penelitian ini berdistribusi normal.

Tabel 2. Test of Homogeneity of Variances

\begin{tabular}{|r|r|r|r|}
\hline $\begin{array}{c}\text { Levene } \\
\text { Statistic }\end{array}$ & f1 & f2 & ig. \\
\hline .742 & & & \\
& & 9 & 619 \\
\hline
\end{tabular}

Pada abel 2 terlihat bahwa sig 0,619>0,05, dengan demikian $\mathrm{H}_{0}$ diterima dan $\mathrm{H}_{1}$ ditolak yang artinya data berasal populasi yang homogen.

Pengujian hipotesis penelitian ini dilakukan dengan menggunakan uji- $t$ dengan bantuan Microsoft Excel 2010. Berikut ini adalah hasil pengujiannya. 
78 Pengaruh Metode Pembelajaran Discovery dan Metode Pembelajaran Inquiri terhadap Kemampuan Pemecahan Masalah Matematika Teknik

Tabel 3. Hasil Perhitungan Pengujian Hipotesis Penelitian

\begin{tabular}{|c|c|c|}
\hline $\begin{array}{l}\text { Nomor Urut } \\
\text { Responden }\end{array}$ & $\mathrm{X} 1$ & $\mathrm{X} 2$ \\
\hline 1 & 65 & 75 \\
\hline 2 & 75 & 65 \\
\hline 3 & 78 & 72 \\
\hline 4 & 72 & 72 \\
\hline 5 & 75 & 65 \\
\hline 6 & 72 & 75 \\
\hline 7 & 72 & 84 \\
\hline 8 & 75 & 72 \\
\hline 9 & 72 & 65 \\
\hline 10 & 75 & 72 \\
\hline 11 & 75 & 84 \\
\hline 12 & 72 & 75 \\
\hline 13 & 72 & 65 \\
\hline 14 & 70 & 72 \\
\hline 15 & 70 & 72 \\
\hline 16 & 84 & 72 \\
\hline 17 & 70 & 75 \\
\hline 18 & 70 & 72 \\
\hline 19 & 70 & 70 \\
\hline 20 & 75 & 72 \\
\hline 21 & 79 & 72 \\
\hline 22 & 75 & 75 \\
\hline 23 & 79 & 65 \\
\hline 24 & 84 & 70 \\
\hline 25 & 65 & 70 \\
\hline 26 & 75 & 78 \\
\hline 27 & 65 & 70 \\
\hline 28 & 75 & 70 \\
\hline
\end{tabular}

Perhitungan:

$$
\begin{aligned}
& t=\frac{\overline{X_{1}}-\overline{X_{2}}}{\sqrt{\frac{\left(n_{1}-1\right) s_{1}^{2}+\left(n_{2}-1\right) s_{2}^{2}}{n_{1}+n_{2}-2}\left(\frac{1}{n_{1}}+\frac{1}{n_{2}}\right)}} \\
& t=\frac{73-72}{\sqrt{\frac{(28-1) \cdot 23+(28-1) 23}{28+28-2}\left(\frac{1}{28}+\frac{1}{28}\right)}} \\
& t=0,866
\end{aligned}
$$

Dari hasil perhitungan menggunakan korelasi uji-t diperoleh nilai $t_{\text {hitung }}=0,866$.
Nilai $t_{\text {hitung }}$ tersebut kemudian dikonsultasikan dengan $r_{\text {tabel }}$ dengan derajat kebebasan 56 pada taraf signifikan 5\% dimana diperoleh $r_{\text {tabel }}=$ 1,674 . Sehingga $t_{\text {hitung }}<t_{\text {tabel }}$ maka Ho diterima dan menolak $\mathrm{Ha}$ yang menayatakan "Tidak ada perbedaan kemampuan pemecahan masalah matematika teknik yang diajar menggunakan metode pembelajaran discovery dan metode pembelajaran inquiri pada mahasiswa semester 1 Prodi Arsitektur Universitas Indraprasta PGRI tahun ajaran 2019/2020".

\section{Pembahasan}

Setelah melakukan penelitian, peneliti menyimpulkan bahwa tidak ada perbedaan kemampuan pemecahan masalah matematika teknik yang diajar menggunakan metode pembelajaran discovery dan metode pembelajaran inquiri pada mahasiswa semester 1 Prodi Arsitektur Universitas Indraprasta PGRI tahun ajaran 2019/2020. Hal ini dapat dibuktikan dari perhitungan menggunakan uji-t.

Berdasarkan hasil pengamatan dan wawancara dengan mahasiswa semester 1 Prodi Arsitektur Universitas Indraprasta PGRI dengan materi Perbandingan, terdapat beberapa mahasiswa yang mengalami kendala dalam menyelesaikan soal perbandingan yang berhubungan dengan pemecahan masalah. Kurangnya kreatifitas mahasiswa dalam memecahkan masalah matematika teknik, mereka tidak ingin menemukan cara lain dalam menyelesaikan soal-soal yang diberikan pengajar.

\section{PENUTUP}

\section{Simpulan}

Berdasarkan landasan teori dan didukung analisis data serta mengacu pada perumusan masalah yang telah diuraikan pada bab sebelumnya, maka dapat diambil kesimpulan tidak ada perbedaan kemampuan pemecahan masalah matematika teknik yang diajar menggunakan metode pembelajaran discovery dan metode pembelajaran inquiri pada mahasiswa semester 1 Prodi Arsitektur Universitas Indraprasta PGRI tahun ajaran 2019/2020. Hal ini dapat dibuktikan 
dari hasil perhitungan menggunakan uji-t dengan derajat kebebasan 56 pada taraf signifikan 5\% dimana diperoleh diperoleh nilai $t_{\text {hitung }}=0,866$ $<t_{\text {tabel }}=1,674$.

\section{Saran}

Berdasarkan pada simpulan penelitian, maka berikut ini diajukan saran untuk perbaikan bagi peneliti lain yang akan meneliti kemampuan pemecahan masalah matematika teknik sebagai berikut :

1. Pengajar hendaknya membimbing mahasiswa dalam menemukan solusi untuk memecahkan masalah matematika teknik.

2. Pengajar mencari strategi dan metode pembelajaran yang tepat agar mahasiswa mudah memahami dan menyelesaikan soal.

3. Pengajar hendaknya dapat menciptakan suasana belajar yang kondusif yang dapat meningkatkan semangat dalam belajar.

\section{DAFTAR RUJUKAN}

Arikunto, Suharsimi. 1996. Prosedur Penelitian Suatu Pendekatan Praktek. Jakarta: Rineka Cipta.

Arikunto, Suharsimi. 2002. Prosedur Penelitian: Suatu Pendekatan Praktik. Jakarta: Rineka Cipta.

Branca, Nicholas A. 1980. Problemsolving as a goal, Process and Basic Skill. Reston Virginia: NCTM.

Gulo, W. 2002. Strategi Belajar Mengajar. Jakarta: PT. Grafindo.

Hudoyo. 1997. Matematika. Dirjen Dikti. BP3GD.

Nasution. 1992. Berbagai Pendekatan dalam Proses Belajar Mengajar. Jakarta: Bumi Aksara.

Polya. 1973. How To Solve It, A New Aspect of Mathematics Grades 3-6, Powerfull Strategies in Deepen Understanding. USA. Corwin.

Ruseffendi, E.T. 1991. Pengantar kepaa Guru: Membantu Mengembangkan Potensinya dalam Pengajaran Matematika untuk Meningkatkan CBSA. Bandung: Tarsito.

Sanjaya, Wina. 2008. Strategi Pembelajaran Berorientasi Standar Proses Pendidikan. Jakarta: Kencana Prenada Media Group.

Sumantri, Mulyani dan Johan Permana. 1999. Straegi Belajar Mengajar. Jakarta: Depdikbud Dirjen Dikti.

Usman, Moh Uzer. 2008. Menjadi Guru Profesional. Bandung: PT. Remaja Rosdakarya.

Zulkardi. 2007. Beberapa Catatan KTSP dan PMRI Work Shop PMRI. Yogyakarta : PPPG Matematika. 